\title{
Current situation regarding lead exposure in birds in Japan (2015-2018); lead exposure is still occurring
}

\author{
Chihiro ISHII ${ }^{1)}$, Yoshinori IKENAKA ${ }^{1,2)}$, Shouta M.M. NAKAYAMA ${ }^{1)}$ \\ Takeshi KURITANI ${ }^{3)}$, Mitsuhiro NAKAGAWA ${ }^{3)}$, Keisuke SAITO4), \\ Yukiko WATANABE ${ }^{4)}$, Kohei OGASAWARA4), Manabu ONUMA ${ }^{5)}$, \\ Atsushi HAGA ${ }^{5)}$ and Mayumi ISHIZUKA ${ }^{1) *}$
}
1)Laboratory of Toxicology, Department of Environmental Veterinary Sciences, School of Veterinary Medicine, Hokkaido University, Kita18, Nishi9, Kita-ku, Sapporo, Hokkaido 060-0818, Japan
${ }^{2)}$ Water Research Group, Unit for Environmental Sciences and Management, North-West University, 11 Hoffman Street, Potchefstroom, 2531, South Africa
${ }^{3)}$ Graduate School of Science, Hokkaido University, Kita10, Nishi8, Kita-ku, Sapporo, Hokkaido 060-0810, Japan
4)Institute for Raptor Biomedicine Japan, 2-2101 Hokuto, Kushiro-shi, Hokkaido 084-0922, Japan
${ }^{5)}$ National Institute for Environmental Studies, 16-2 Onogawa, Tsukuba, Ibaraki 305-8506, Japan

\section{J. Vet. Med. Sci.}

82(8): 1118-1123, 2020

doi: 10.1292/jvms.20-0104

Received: 28 February 2020

Accepted: 28 May 2020

Advanced Epub:

18 June 2020

\begin{abstract}
Birds of a number of species have died as a result of lead $(\mathrm{Pb})$ poisoning, including many Steller's sea eagles (Haliaeetus pelagicus) and white-tailed sea eagles (Haliaeetus albicilla) in Hokkaido, the northernmost island of Japan. To address this issue, the use of any type of $\mathrm{Pb}$ ammunition for hunting of large animals was prohibited in Hokkaido in 2004. However, $\mathrm{Pb}$ poisoning is still being reported in this area, and there are few regulations regarding the use of $\mathrm{Pb}$ ammunition in other parts of Japan, where it has been reported that eagles and water birds have been exposed to $\mathrm{Pb}$. This study was performed to accurately determine the current level of $\mathrm{Pb}$ exposure of birds found dead in the field or dead in the wild bird centers in Japan (June 2015-May 2018) and to identify the sources of $\mathrm{Pb}$. Pb exposure was found to still be occurring in raptors and water birds in various parts of Japan. Twenty-six point five $\%$ and $5.9 \%$ of the recorded deaths of Steller's sea eagles and white-tailed sea eagles, respectively, were found to have been poisoned by $\mathrm{Pb}$. In addition, $\mathrm{Pb}$ isotope ratio analysis showed that both $\mathrm{Pb}$ rifle bullets and $\mathrm{Pb}$ shot pellets cause $\mathrm{Pb}$ exposure in birds, and these endangered eagles are also exposed to $\mathrm{Pb}$ in Hokkaido due to the illegal use of $\mathrm{Pb}$ ammunition. Changing to $\mathrm{Pb}$-free ammunition, such as copper $(\mathrm{Cu})$ rifle bullets, steel shot pellets, or bismuth shot pellets, will be essential for the conservation of avian species in Japan.
\end{abstract}

KEY WORDS: $\mathrm{Pb}$ ammunition, $\mathrm{Pb}$ exposure, $\mathrm{Pb}$ isotope ratios, raptor, water bird

Birds of a number of species have died as a result of lead $(\mathrm{Pb})$ poisoning, including at least 33 raptors, 30 other terrestrial bird species, and water birds in the world $[1,23]$. Furthermore, both the number of taxa affected and geographical spread of cases have increased [24]. Raptors can experience secondary $\mathrm{Pb}$ poisoning from feeding on animals with $\mathrm{Pb}$ ammunition embedded in their tissues, while water birds commonly suffer from $\mathrm{Pb}$ poisoning through ingestion of $\mathrm{Pb}$ shot pellets or sinkers lying in lakes and marshes, which they mistake for grit $[2,8,27]$. When raptors consume these water birds, they are also exposed to $\mathrm{Pb}$.

$\mathrm{Pb}$ is an accumulative metabolic poison that produces toxic effects in a wide range of physiological and biochemical systems, including the hematopoietic, vascular, nervous, renal, immune, and reproductive systems, and elevated accumulation of $\mathrm{Pb}$ leads to high mortality rates $[13,24]$. Sublethal doses of $\mathrm{Pb}$ alter movement behaviors [5] and affect sperm quality and reproductive success [29]. There is also a possibility that birds exposed to $\mathrm{Pb}$ cannot migrate. The ecological significance of mortalities and the effect on reproductive system associated with $\mathrm{Pb}$ exposure must be viewed within the context of cumulative risks to avian populations [13].

Although the use of $\mathrm{Pb}$ in gasoline, paints, and various household items is prohibited because of its toxicity, $\mathrm{Pb}$ ammunition is still widely used for hunting and shooting [1]. Non- $\mathrm{Pb}$ shot, such as copper $(\mathrm{Cu})$ rifle bullets or iron-tungsten-nickel shot pellets, have been developed $[3,7]$ and their efficacy has been demonstrated [12]. However, there are few nationally regulated bans on the

*Correspondence to: Ishizuka, M.: ishizum@vetmed.hokudai.ac.jp

(Supplementary material: refer to PMC https://www.ncbi.nlm.nih.gov/pmc/journals/2350/)

(O2020 The Japanese Society of Veterinary Science

This is an open-access article distributed under the terms of the Creative Commons Attribution Non-Commercial No Derivatives (by-nc-nd) License. (CC-BY-NC-ND 4.0: https://creativecommons.org/licenses/by-nc-nd/4.0/) 
use of $\mathrm{Pb}$ ammunition despite the scientific evidence for the risks it poses and increasing policy imperatives [1].

In Hokkaido, the northernmost island of Japan, many Steller's sea eagles (Haliaeetus pelagicus) and white-tailed sea eagles (Haliaeetus albicilla) have died from $\mathrm{Pb}$ poisoning after ingesting $\mathrm{Pb}$ fragments from sika deer (Cervus nippon) carcasses. The number of sika deer is increasing in Hokkaido, and hunting is needed for management of their population. Due to the toxicity of $\mathrm{Pb}$, it is required to use copper $(\mathrm{Cu})$ rifle bullets or slugs instead of $\mathrm{Pb}$ bullets for hunting sika deer. A regulation to ban the use of $\mathrm{Pb}$ rifle bullets for hunting sika deer was introduced in 2000, and the use of $\mathrm{Pb}$ shot pellets for hunting sika deer was prohibited in 2001. In addition, an extended ban was initiated in 2004, which prohibited the use of any type of $\mathrm{Pb}$-containing ammunition for hunting large animal species. This regulation was enforced in 2014, prohibiting the possession of $\mathrm{Pb}$ rifle bullets, slugs, or large shot pellets during hunting; prior to this regulation, it was not illegal to carry $\mathrm{Pb}$ ammunition when hunting, but hunters were punished if they were found to have used such ammunition. However, although more than 10 years have passed since the introduction of legislation regarding $\mathrm{Pb}$ ammunition, $\mathrm{Pb}$ poisoning is still being reported in Hokkaido [10]. In other parts of Japan, both regulations and surveillance were less extensive than in Hokkaido, however, eagles and water birds were exposed to $\mathrm{Pb}[9,11,20]$.

Various thresholds for $\mathrm{Pb}$ toxicity in birds have been reported in the literature $[6,13,14,18,26]$. The background level of $\mathrm{Pb}$ in the liver is generally $<2 \mathrm{mg} / \mathrm{kg}$ wet weight (6-7 mg/kg dry weight) or $<1 \mathrm{mg} / \mathrm{kg}$ wet weight (3 mg/kg dry weight) in raptors [21]. Some authors have reported that a liver $\mathrm{Pb}$ concentration of $>6 \mathrm{mg} / \mathrm{kg}$ dry weight in raptors indicates abnormally high exposure to $\mathrm{Pb}$, while a concentration of $>20 \mathrm{mg} / \mathrm{kg}$ dry weight indicates acute exposure and absorption, resulting in $\mathrm{Pb}$ poisoning [21, 22]. The following categories are used in Japan based on the hepatic $\mathrm{Pb}$ concentration in wet weight: $<0.2 \mathrm{mg} / \mathrm{kg}$, normal range; $0.2-2 \mathrm{mg} /$ $\mathrm{kg}$, high level of $\mathrm{Pb}$ exposure; and $>2 \mathrm{mg} / \mathrm{kg}$, $\mathrm{Pb}$ poisoning [24].

The relative abundances of the naturally occurring isotopes of $\mathrm{Pb}\left({ }^{204} \mathrm{~Pb},{ }^{206} \mathrm{~Pb},{ }^{207} \mathrm{~Pb}\right.$, and $\left.{ }^{208} \mathrm{~Pb}\right)$ vary among industrial materials, allowing the isotope ratios in organisms to be used to determine the source of $\mathrm{Pb}$ exposure, as reported previously in raptors [4]. The following $\mathrm{Pb}$ isotope ratios $\left({ }^{208} \mathrm{~Pb} /{ }^{206} \mathrm{~Pb},{ }^{207} \mathrm{~Pb} /{ }^{206} \mathrm{~Pb}\right)$ were reported for various types of $\mathrm{Pb}$ ammunition obtained from stores in Japan: rifle bullets, $1.90-2.10$ and $0.75-0.88$; shot pellets, $2.07-2.14$ and $0.85-0.87$; and fishing sinkers, $2.08-2.20$ and $0.84-0.90$. These materials had been purchased or collected from the carcasses of birds up until 2001. We confirmed that the $\mathrm{Pb}$ isotope ratios of $\mathrm{Pb}$ rifle bullets, shot pellets, and fishing sinkers used by hunters and fishermen recently were comparable to these values and the results of $\mathrm{Pb}$ isotope ratio in the liver of bird would reflect that in the main source of exposure [10].

This study was performed to accurately determine the current levels of $\mathrm{Pb}$ exposure in wild birds carried to clinics or wild bird centers in Japan (June 2015-May 2018) and to identify the sources of Pb by analyzing the Pb isotope ratios.

\section{MATERIALS AND METHODS}

\section{Sampling}

Liver specimens from the carcasses of birds were obtained from the Institute for Raptor Biomedicine Japan, National Institute for Environmental Studies, or wild bird centers for analysis of their $\mathrm{Pb}$ concentrations and $\mathrm{Pb}$ isotope ratios. Samples were collected from June 2015 to May 2018 from the following locations and species: from Hokkaido, white-tailed sea eagle ( $n=51)$, Steller's sea eagle $(n=34)$, Blakiston's fish owl (Ketupa blakistoni) $(n=7)$, mountain hawk eagle (Spizaetus nipalensis) $(n=3)$, northern goshawk (Accipiter gentilis) $(n=3)$, Eurasian hobby (Falco subbuteo) $(n=2)$, peregrine falcon $($ Falco peregrinus) $(n=1)$, sparrow hawk (Accipiter nisus) $(n=1)$, ural owl (Strix uralensis japonica) $(n=1)$, jungle crow (Corvus macrorhynchos) $(n=2)$, and whooper swan (Cygnus cygnus) $(n=1)$; from Honshu (the main island) or Kyushu (southwestern island), peregrine falcon ( $n=6)$, northern goshawk $(n=5)$, sparrow hawk $(n=4)$, ural owl $(n=4)$, mountain hawk eagle $(n=2)$, whooper swan $(n=2)$, and greater white-fronted goose (Anser albifrons) $(n=2)$. Swans that had died in one lake in Honshu (see Introduction) were not included in the analysis to exclude any potential sampling bias around the ratio of $\mathrm{Pb}$ exposure in swans. The specimens were transported to the School of Veterinary Medicine, Hokkaido University, Sapporo, Japan, where they were stored at $-20^{\circ} \mathrm{C}$ until analysis. The ages of raptors were estimated from their morphological characteristics, such as the development of the gonads and feathers, the color of their feathers and iris, and molting condition [19]. Sampling areas are shown in Supplementary Fig. 1 and individual information is shown in Supplementary Table 3. The map information for Supplementary Fig. 1 was downloaded from Geospatial Information Authority of Japan and depicted by sf package [25] and ggplot2 [30] on R software ver. 3.5.1 [28].

Four shot pellets from the stomach of a whooper swan and fragments of $\mathrm{Pb}$ ammunition from the stomachs of two Steller's sea eagles were also collected to analyze the $\mathrm{Pb}$ isotope ratios in $\mathrm{Pb}$ ammunition.

\section{Pb concentration}

$\mathrm{Pb}$ concentrations were analyzed according to the method of Yabe et al. [31]. Samples of 100-300 mg of soft tissues were digested with $5 \mathrm{~m} l$ of $30 \%$ nitric acid (Kanto Chemical Corp., Tokyo, Japan) and $1 \mathrm{~m} l$ of $30 \%$ hydrogen peroxide (Kanto Chemical Corp.) in a microwave digestion system (Speedwave Two; Berghof, Eningen, Germany), after which the volume was made up to $10 \mathrm{ml}$ by adding $2 \%$ nitric acid. Digestion was performed under the following conditions: $180^{\circ} \mathrm{C}$ for $15 \mathrm{~min}, 200^{\circ} \mathrm{C}$ for $20 \mathrm{~min}$, and $100^{\circ} \mathrm{C}$ for $20 \mathrm{~min}$. The $\mathrm{Pb}$ concentration and isotope ratios were then measured using an inductively coupled plasma-mass spectrometer (ICP-MS) (7700 series; Agilent Technology, Tokyo, Japan) (see Supplementary Table 1 for detailed analytical conditions), which was calibrated using ICP-MS Calibration Standards (Agilent Technology) to establish standard curves before analysis. Standard solutions $\left(0,10,50,100,250\right.$, and $500 \mu \mathrm{g} / l$ were prepared with $2 \%$ nitric acid and the standard curves had $\mathrm{r}^{2}$ values of 0.998. All chemicals and standard stock solutions were of analytical reagent grade (Wako Pure Chemicals Industries, Osaka, Japan). Distilled and deionized water was used (Milli-Q; Merck Millipore, Billerica, MA, USA), and analytical quality 
control was performed using DOLT-4 (dogfish liver) and DORM-3 (fish protein) certified reference materials (National Research Council of Canada, Ottawa, ON, Canada), which were shown to have good recoveries (95-105\%) through replicate analysis. Thallium $\left({ }^{205} \mathrm{Tl}\right)$ was used as an internal standard for the $\mathrm{Pb}$ concentration analysis. The limit of detection for $\mathrm{Pb}$ was $0.001 \mu \mathrm{g} / \mathrm{kg}$.

\section{$\mathrm{Pb}$ isotope analysis}

The chemical procedures were carried out in a clean room with a Class 1000. The sample dissolution procedure was similar to the method described by Kuritani and Nakamura [16]. The extracted solutions of liver were transferred into Teflon tubes after analysis of $\mathrm{Pb}$ levels. One drop $(\sim 30 \mu l)$ of $0.05 \mathrm{~N}$ phosphoric acid (orthophosphoric acid 85\%; Merck KGaA, Darmstadt, Germany) was added to the tubes to avoid complete dryness prior to evaporation. The mixed solution was dried for $15 \mathrm{hr}$ on a hotplate at $100^{\circ} \mathrm{C}$. After evaporation, three drops $(\sim 90 \mu l)$ of $8 \mathrm{~N}$ hydrogen bromide (once distilled, Analytical Grade $48 \%$; Kanto Chemical Corp.) was added to the tubes. The tubes were placed on a hotplate at $120^{\circ} \mathrm{C}$ for $1 \mathrm{hr}$ for re-drying. At the final step of pre-treatment before applying to the column, $0.3 \mathrm{~m} l$ of $0.5 \mathrm{~N}$ hydrogen bromide was introduced into the tube to dissolve residues. A polyethylene column was charged with $0.1 \mathrm{~m} l$ of anion exchange resin (AG1-X8, analytical grade, 200-400 mesh, chloride form; Bio-Rad, Hercules, CA, USA). The resin bed was washed by flushing the column with $1.0 \mathrm{~m} l$ of $0.5 \mathrm{~N}$ nitric acid (EL Grade $61 \%$; Kanto Chemical Corp.) followed by $1.0 \mathrm{ml}$ of double distilled deionized water, at a rate of $\sim 0.03 \mathrm{ml} / \mathrm{min}$. The column was conditioned with $0.2 \mathrm{~m} l$ of $0.5 \mathrm{~N}$ hydrogen bromide. The sample dissolved in $0.3 \mathrm{~m} l$ of $0.5 \mathrm{~N}$ hydrogen bromide was loaded onto the column. To wash out residual organic compounds originally derived from liver samples, $0.3 \mathrm{~m} l$ of $0.5 \mathrm{~N}$ hydrogen bromide was introduced twice. Subsequently, $0.8 \mathrm{~m} l$ of $0.25 \mathrm{~N}$ hydrogen bromide- $0.5 \mathrm{~N}$ nitric acid mixture was applied to the column to remove elements other than $\mathrm{Pb}$. Finally, the column was washed again with $0.1 \mathrm{~m} l$ of double distilled deionized water. After all washing procedures, $1.3 \mathrm{ml}$ of $3 \%$ nitric acid was introduced to drop $\mathrm{Pb}$ out from the resin. Then, $2 \mu l \mathrm{of} 50 \mathrm{mg} / \mathrm{l}$ thallium (Tl) was added to $\mathrm{Pb}$ eluted solution as an external standard for the analytical procedure.

$\mathrm{Pb}$ isotopic ratios of ${ }^{208} \mathrm{~Pb} /{ }^{206} \mathrm{~Pb}$ and ${ }^{207} \mathrm{~Pb} /{ }^{206} \mathrm{~Pb}$ were determined on a multiple collector (MC)-ICP-MS (Neptune Plus; Thermo Finnigan, San Jose, CA, USA) in static mode with the Faraday cup configuration. Other general parameters are described in Supplementary Table 2. Mass fractionation factors for Pb were corrected using an external standard of Tl. In addition, mass-dependent inter-element fractionations were also corrected by applying a standard bracketing method using NIST SRM 981 (National Institute of Standards and Technology, Gaithersburg, MD, USA), and the data were finally normalized to ${ }^{206} \mathrm{~Pb} /{ }^{204} \mathrm{~Pb}=16.9424,{ }^{207} \mathrm{~Pb} /{ }^{204} \mathrm{~Pb}=15.5003$, and ${ }^{208} \mathrm{~Pb} /{ }^{204} \mathrm{~Pb}=36.7266$ [17]. The $2 \mathrm{SE}$ values of ${ }^{208} \mathrm{~Pb} /{ }^{206} \mathrm{~Pb}$ or ${ }^{207} \mathrm{~Pb} /{ }^{206} \mathrm{~Pb}$ were $<0.0002$.

\section{Statistical analysis}

Differences in the Pb concentrations between Steller's sea eagles and white-tailed sea eagles were analyzed using the MannWhitney $U$ test. Statistical analysis was performed with JMP Pro 14 (SAS Institute, Cary, NC, USA). In all analyses, $P<0.05$ was taken to indicate statistical significance.

\section{RESULTS}

In total, nine of 34 Steller's sea eagles (26.5\%) and three of 51 white-tailed sea eagles (5.9\%) from Hokkaido, and two whooper swans from Hokkaido or Honshu exceeded the background level of $\mathrm{Pb}$ poisoning (i.e., $>2 \mathrm{mg} / \mathrm{kg}$ wet weight of $\mathrm{Pb}$ in the liver). In addition, two white-tailed sea eagles, three Steller's sea eagles, and one Eurasian hobby from Hokkaido, and one mountain hawk eagle and one greater white-fronted goose from Honshu showed high Pb exposure (0.2-2 mg/kg) (Tables 1 and 2, Supplementary Fig. 2).

As for the species difference between Steller's sea eagles and white-tailed sea eagles, statistical analysis showed that Steller's

Table 1. Hepatic $\mathrm{Pb}$ levels (mg/kg, wet weight, range) and the assesments of $\mathrm{Pb}$ exposure in birds from Hokkaido

\begin{tabular}{|c|c|c|c|c|c|}
\hline \multirow[b]{2}{*}{ Species } & \multirow{2}{*}{$\begin{array}{l}\text { Sample } \\
\text { size }\end{array}$} & \multirow{2}{*}{$\begin{array}{c}\mathrm{Pb} \text { concentration in liver } \\
\mathrm{mg} / \mathrm{kg} \text {, wet wt, median, } \\
\text { (range) }\end{array}$} & \multicolumn{3}{|c|}{ Assessments } \\
\hline & & & $\begin{array}{l}\text { Pb poisoning } \\
(>2.0 \text { mg.kg) }\end{array}$ & $\begin{array}{l}\text { High } \mathrm{Pb} \text { exposure } \\
(0.2-2.0 \mathrm{mg} / \mathrm{kg})\end{array}$ & $\begin{array}{c}\text { Non toxic } \\
(<0.2 \mathrm{mg} / \mathrm{kg})\end{array}$ \\
\hline White-tailed sea eagle & 51 & $0.068(0.003-50.79)$ & 3 & 2 & 46 \\
\hline Steller's sea eagle & 34 & $0.082(0.003-72.01)$ & 9 & 3 & 22 \\
\hline Blakiston's fish-owl & 7 & $0.036(0.001-0.070)$ & 0 & 0 & 7 \\
\hline Mountain hawk-eagle & 3 & $0.095(0.023-0.120)$ & 0 & 0 & 3 \\
\hline Northern goshawk & 3 & $0.025(0.007-0.136)$ & 0 & 0 & 3 \\
\hline Eurasian Hobby & 2 & $(0.092,0.278)$ & 0 & 1 & 1 \\
\hline Jungle crow & 2 & $(0.063,0.107)$ & 0 & 0 & 2 \\
\hline Peregrine falcon & 1 & 0.093 & 0 & 0 & 1 \\
\hline Sparrow hawk & 1 & 0.065 & 0 & 0 & 1 \\
\hline Ural owl & 1 & 0.137 & 0 & 0 & 1 \\
\hline Whooper swan & 1 & 19.56 & 1 & 0 & 0 \\
\hline
\end{tabular}


Table 2. Hepatic $\mathrm{Pb}$ levels (mg/kg, wet weight, range) and the assesments of $\mathrm{Pb}$ exposure in birds from Honshu or Kyushu

\begin{tabular}{lccccc}
\hline \multirow{2}{*}{ Species } & \multirow{2}{*}{$\begin{array}{c}\text { Sample } \\
\text { size }\end{array}$} & Pb concentration in liver & \multicolumn{3}{c}{ Assessments } \\
\cline { 5 - 6 } & & & $\begin{array}{c}\text { Pb poisoning } \\
(>2.0 \mathrm{mg} . \mathrm{kg})\end{array}$ & $\begin{array}{c}\text { High Pb exposure } \\
(0.2-2.0 \mathrm{mg} / \mathrm{kg})\end{array}$ & $\begin{array}{c}\text { Non toxic } \\
(<0.2 \mathrm{mg} / \mathrm{kg})\end{array}$ \\
\hline Peregrine falcon & 6 & $0.050(0.023-0.095)$ & 0 & 0 & 5 \\
Northern goshawk & 5 & $0.080(0.032-0.157)$ & 0 & 0 & 5 \\
Sparrowhawk & 4 & $0.047(0.017-0.080)$ & 0 & 0 & 3 \\
Ural owl & 4 & $0.031(0.015-0.054)$ & 0 & 0 & 3 \\
Mountain hawk-eagle & 2 & $(0.051,0.705)$ & 0 & 1 & 1 \\
Whooper swan & 2 & $(0.182,19.58)$ & 1 & 0 & 1 \\
Greater white-fronted goose & 2 & $(0.097,0.719)$ & 0 & 1 & 1 \\
\hline
\end{tabular}

Table 3. Pb isotope ratios in liver and ammunition from the stomach of Steller's sea eagle and whooper swan

\begin{tabular}{llcc}
\hline & \multicolumn{1}{c}{ Sample } & \multicolumn{2}{c}{ Pb isotope ratios } \\
\cline { 3 - 4 } Steller's sea eagle & Liver & $208 / 206 \mathrm{~Pb}$ & $207 / 206 \mathrm{~Pb}$ \\
\cline { 2 - 3 } Steller's sea eagle & 2.05 & 0.84 \\
& Ammunition from the stomach & 2.11 & 0.84 \\
& Liver & 2.11 & 0.87 \\
& Ammunition from the stomach_1 & 2.11 & 0.87 \\
& Ammunition from the stomach_2 & 2.11 & 0.87 \\
& Ammunition from the stomach_3 & 2.13 & 0.87 \\
& Liver & 2.16 & 0.88 \\
& Ammunition from the stomach_1 & 2.12 & 0.90 \\
& Ammunition from the stomach_2 & 2.10 & 0.87 \\
& Ammunition from the stomach_3 & 2.10 & 0.86 \\
& Ammunition from the stomach_4 & 2.12 & 0.86 \\
& Avarage of the above ammunition & & 0.87 \\
\hline
\end{tabular}

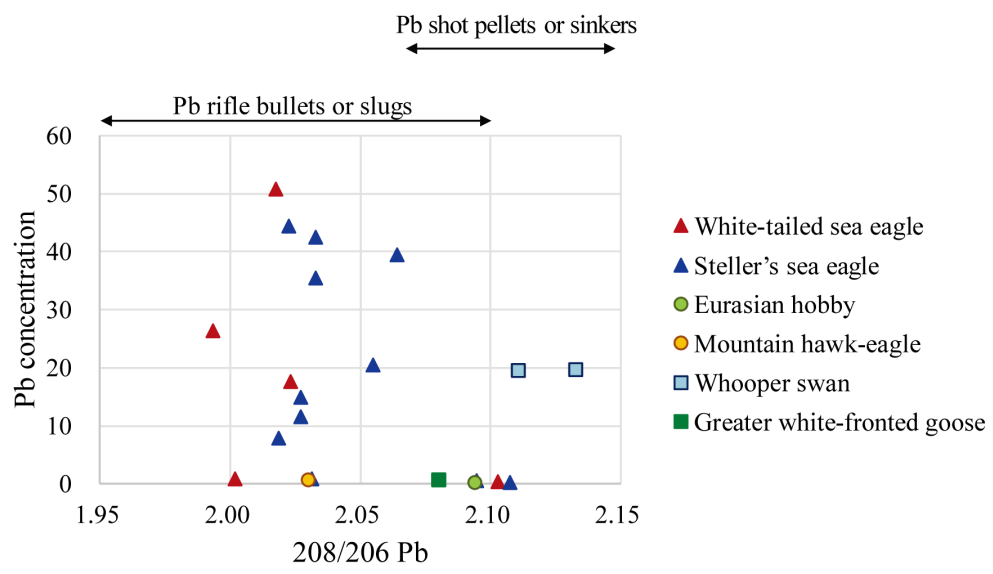

Fig. 1. Comparison of (a) $\mathrm{Pb}$ concentration and $\mathrm{Pb}$ isotope ratio $\left({ }^{208} \mathrm{~Pb} / 206 \mathrm{~Pb}\right)$ in the livers of birds that had high $\mathrm{Pb}$ concentrations $(>0.2 \mathrm{mg} / \mathrm{kg}$, wet weight).

sea eagles accumulated higher levels of $\mathrm{Pb}$ than white-tailed sea eagles, and there was a significant difference $(P<0.03)$.

The fragments of $\mathrm{Pb}$ ammunition extracted from the stomachs of two Steller's sea eagles had the same isotope ratios as occurred in the livers of the same individuals. A whooper swan showed the same isotope ratios in its liver as the midrange of the isotope ratios of the four pieces of ammunition found in its stomach (Table 3).

$\mathrm{The} \mathrm{Pb}$ isotope ratios of almost all of the white-tailed sea eagles and Steller's sea eagles, and one mountain hawk eagle were very similar to those of $\mathrm{Pb}$ rifle bullets or slugs (Fig. 1). While several sea eagles, one Eurasian hobby, whooper swans, and one greater white-fronted goose had similar $\mathrm{Pb}$ isotope ratios with $\mathrm{Pb}$ shot pellets or sinkers (Fig. 1). All data are shown in Supplementary Table 3. 


\section{DISCUSSION}

$\mathrm{Pb}$ exposure in birds was shown to have occurred in both Hokkaido and Honshu. Despite prohibition of the use of $\mathrm{Pb}$ ammunition, endangered eagles were poisoned by $\mathrm{Pb}$ in Hokkaido. $\mathrm{Pb}$ poisoning has a large effect to the population of endangered eagles. Birds were also exposed to $\mathrm{Pb}$ in Honshu where regulation of the use of $\mathrm{Pb}$ ammunition is limited. As the sample number from Honshu was small, they may represent only a portion of the total number of cases.

As for the species difference between Steller's sea eagles and white-tailed sea eagles, Steller's sea eagles accumulated higher levels of $\mathrm{Pb}$ than white-tailed sea eagles $(P<0.03)$. A previous study showed the same situation in Japan [10]. Steller's sea eagles have a higher risk of ingesting $\mathrm{Pb}$ from deer carcasses because their body size is larger than white-tailed sea eagles, and they regularly defeat white-tailed sea eagles to feed on deer carcasses. Furthermore, many sea eagles change their main food source from fish to deer during the hunting season. This tendency to change their diet is stronger in the Steller's sea eagle.

$\mathrm{The} \mathrm{Pb}$ isotope ratios indicated that almost all of the white-tailed sea eagles and Steller's sea eagles examined were exposed to $\mathrm{Pb}$ from $\mathrm{Pb}$ rifle bullets or slugs, while several sea eagles had ingested $\mathrm{Pb}$ shot pellets or sinkers (Fig. 1). One mountain hawk eagle was found to contain $\mathrm{Pb}$ from a $\mathrm{Pb}$ rifle bullet, while one Eurasian hobby, whooper swans, and one greater white-fronted goose had ingested $\mathrm{Pb}$ shot pellets or sinkers (Fig. 1). $\mathrm{Pb}$ isotope ratio analysis showed that both $\mathrm{Pb}$ rifle bullets and $\mathrm{Pb}$ shot pellets cause $\mathrm{Pb}$ exposure in birds, and endangered eagles are also exposed to $\mathrm{Pb}$ in Hokkaido due to the illegal use of $\mathrm{Pb}$ ammunition. In addition, only limited numbers of birds were obtained from Honshu and Kyushu, but it was clear that birds here were also exposed to $\mathrm{Pb}$ from $\mathrm{Pb}$ shot pellets or sinkers. The observation that one swan contained four different $\mathrm{Pb}$ isotope ratios in four $\mathrm{Pb}$ shot pellets indicated that several types of $\mathrm{Pb}$ shot pellets had been used in the same area.

Previous study showed that $42 \%$ of Steller's sea eagles (18 of 43 cases) and 24\% of white-tailed sea eagles (12 of 50 cases) exceeded the level of $\mathrm{Pb}$ poisoning ( $>2 \mathrm{mg} / \mathrm{kg}$ wet weight in liver) and one mountain hawk eagle exceeded the level of high $\mathrm{Pb}$ exposure ( $>0.1 \mathrm{mg} / \mathrm{kg}$ wet weight in blood) from 2004 to 2015 in Hokkaido [10]. In 2014, the regulation was enforced in Hokkaido that prohibited the possession of $\mathrm{Pb}$ rifle bullets, slugs, or large shot pellets for hunting. Prior to this regulation, it was not illegal for hunters to keep $\mathrm{Pb}$ ammunition, but they were punished if they were found to use such ammunition. This study, the ratio of $\mathrm{Pb}$ exposed birds in Hokkaido decreased. It would be because of the enforced regulation, however, $\mathrm{Pb}$ exposure still occurred in Hokkaido due to the illegal use of $\mathrm{Pb}$ ammunition. Previous study also showed that in Honshu and Shikoku (a southern island), threes golden eagles, one black kite, and one northern goshawk were exposed to Pb from 1993 to 2015 [10]. This study also indicated that several birds accumulated high levels of $\mathrm{Pb}$ in Honshu. Recent studies indicated that some partial bans on the use of lead ammunition do little to reduce lead poisoning mortality in raptors and scavengers [24]. Improvement to the regulation to prohibit the use of $\mathrm{Pb}$ ammunition across all parts of Japan is required to conserve avian species.

It has been demonstrated that $\mathrm{Pb}$-free ammunition, such as copper $(\mathrm{Cu})$ rifle bullets, steel shot pellets, and bismuth, shot pellets, have the same or even greater effectiveness as $\mathrm{Pb}$ ammunition for hunting, and are much less toxic to birds [12, 27]. For example, $\mathrm{Cu}$ toxicity was not confirmed in American kestrel (Falco sparverius) that had ingested $\mathrm{Cu}$ shot pellets [7]. However, $\mathrm{Cu}$ poisoning has sometimes been reported in the waterfowl [15]. Therefore, $\mathrm{Cu}$ rifle bullets or slugs would be useful as alternatives to the $\mathrm{Pb}$ ammunition that is the source of $\mathrm{Pb}$ poisoning in raptors. Steel shot pellets and bismuth pellets should be recommended as alternatives to $\mathrm{Pb}$ shot pellets to protect both raptors and waterfowl from $\mathrm{Pb}$ poisoning. In Hokkaido, the use of $\mathrm{Cu}$ rifle bullets is required instead of $\mathrm{Pb}$ rifle bullets and $\mathrm{Cu}$ rifle bullets are available at stores. Although many hunters in Hokkaido use $\mathrm{Cu}$ rifle bullets, some hunters prefer $\mathrm{Pb}$ rifle bullets to $\mathrm{Cu}$ ones. One of the reasons is $\mathrm{Pb}$ ammunition is inexpensive.

Although the fishing tackle was not found from the stomach of birds in this study, there is also a possibility that fishing sinker is one of the sources of $\mathrm{Pb}$ in birds. The use of all $\mathrm{Pb}$ fishing tackle is prohibited in Denmark, and there are some restrictions on the use of $\mathrm{Pb}$ fishing tackle in European countries, Canada, and the United States to conserve avian species from $\mathrm{Pb}$ exposure [8]. In Japan, anyone can obtain $\mathrm{Pb}$-free fishing tackles at stores, however, information of $\mathrm{Pb}$ exposure in birds from the ingestion of $\mathrm{Pb}$ fishing tackles is not spread sufficiently. The consideration of the use of non-Pb fishing sinkers is also required in Japan.

$\mathrm{Pb}$ exposure is still occurring in raptors and water birds in various parts of Japan. In Hokkaido, both $\mathrm{Pb}$ rifle bullets and $\mathrm{Pb}$ shot pellets cause $\mathrm{Pb}$ exposure in birds, and endangered eagles are also exposed to $\mathrm{Pb}$ due to the illegal use of $\mathrm{Pb}$ ammunition. In Honshu and Kyushu, it was clear that birds were also exposed to $\mathrm{Pb}$ from $\mathrm{Pb}$ shot pellets or sinkers. It is clear that non- $\mathrm{Pb}$ ammunition needs to be used for hunting to reduce $\mathrm{Pb}$ exposure and conserve wild birds. In addition, continuous monitoring for $\mathrm{Pb}$ levels in wild birds to provide the accurate information about $\mathrm{Pb}$ exposure in birds would be important to improve the situation in Japan.

AKNOWLEDGMENTS. We would like to thank Yamashina Institute for Ornithology, Raptor Conservation Center, and The Miyagi Prefectural Izunuma-Uchinuma Environmental Foundation for providing samples. This work was supported by Grants-in-Aid for Scientific Research from the Ministry of Education, Culture, Sports, Science, and Technology of Japan awarded to M. Ishizuka (No. 16H01779), Y. Ikenaka (No. 17K20038, 18H04132), S. Nakayama (No. 16K16197, 17KK0009), and C. Ishii (No. 18H06028). This research was also supported by the Inui Memorial Trust for Research on Animal Science, JST/JICA, SATREPS (Science and Technology Research Partnership for Sustainable Development) and the Environment Research and Technology Development Fund (SII-1/3-2, 4RF-1802/18949907) of the Environmental Restoration and Conservation Agency of Japan. We also acknowledge the financial support by the Nihon Seimei Foundation, the Soroptimist Japan Foundation, the foundations of Sumitomo. We are grateful to Takahiro Ichise, Mai Tamba and Nagisa Hirano (School of Veterinary Medicine, Hokkaido University) for their technical support. 


\section{REFERENCES}

1. Arnemo, J. M., Andersen, O., Stokke, S., Thomas, V. G., Krone, O., Pain, D. J. and Mateo, R. 2016. Health and environmental risks from lead-based ammunition: science versus socio-politics. EcoHealth 13: 618-622. [Medline] [CrossRef]

2. Bellrose, F. C. 1959. Lead poisoning as a mortality factor in waterfowl populations. Bull. Ill. Nat. Hist. Surv. 27: 235-288. [CrossRef]

3. Brewer, L., Fairbrother, A., Clark, J. and Amick, D. 2003. Acute toxicity of lead, steel, and an iron-tungsten-nickel shot to mallard ducks (Anas platyrhynchos). J. Wildl. Dis. 39: 638-648. [Medline] [CrossRef]

4. Church, M. E., Gwiazda, R., Risebrough, R. W., Sorenson, K., Chamberlain, C. P., Farry, S., Heinrich, W., Rideout, B. A. and Smith, D. R. 2006. Ammunition is the principal source of lead accumulated by California condors re-introduced to the wild. Environ. Sci. Technol. 40: 6143-6150. [Medline] [CrossRef]

5. Ecke, F., Singh, N. J., Arnemo, J. M., Bignert, A., Helander, B., Berglund, Å. M. M., Borg, H., Bröjer, C., Holm, K., Lanzone, M., Miller, T., Nordström, Å., Räikkönen, J., Rodushkin, I., Ågren, E. and Hörnfeldt, B. 2017. Sublethal lead exposure alters movement behavior in free-ranging golden eagles. Environ. Sci. Technol. 51: 5729-5736. [Medline] [CrossRef]

6. Fisher, I. J., Pain, D. J. and Thomas, V. G. 2006. A review of lead poisoning from ammunition sources in terrestrial birds. Biol. Conserv. 131: 421-432. [CrossRef]

7. Franson, J. C., Lahner, L. L., Meteyer, C. U. and Rattner, B. A. 2012. Copper pellets simulating oral exposure to copper ammunition: absence of toxicity in American kestrels (Falco sparverius). Arch. Environ. Contam. Toxicol. 62: 145-153. [Medline] [CrossRef]

8. Haig, S. M., D’Elia, J., Eagles-Smith, C., Fair, J. M., Gervais, J., Herring, G., Rivers, J. W. and Schulz, J. H. 2014. The persistent problem of lead poisoning in birds from ammunition and fishing tackle. Condor 116: 408-428. [CrossRef]

9. Honda, K., Lee, D. P. and Tatsukawa, R. 1990. Lead poisoning in swans in Japan. Environ. Pollut. 65: 209-218. [Medline] [CrossRef]

10. Ishii, C., Nakayama, S. M. M., Ikenaka, Y., Nakata, H., Saito, K., Watanabe, Y., Mizukawa, H., Tanabe, S., Nomiyama, K., Hayashi, T. and Ishizuka, M. 2017. Lead exposure in raptors from Japan and source identification using Pb stable isotope ratios. Chemosphere 186: 367-373. [Medline] [CrossRef]

11. Ishii, C., Nakayama, S. M. M., Kataba, A., Ikenaka, Y., Saito, K., Watanabe, Y., Makino, Y., Matsukawa, T., Kubota, A., Yokoyama, K., Mizukawa, H., Hirata, T. and Ishizuka, M. 2018. Characterization and imaging of lead distribution in bones of lead-exposed birds by ICP-MS and LA-ICP-MS. Chemosphere 212: 994-1001. [Medline] [CrossRef]

12. Kanstrup, N., Balsby, T. J. S. and Thomas, V. G. 2016. Efficacy of non-lead rifle ammunition for hunting in Denmark. Eur. J. Wildl. Res. 62: 333-340. [CrossRef]

13. Kendall, R. J., Lacker, T. E., Bunck, C., Daniel, B., Driver, C., Grue, C. E., Leighton, F., Stansley, W., Watanabe, P. G. and Whitworth, M. 1996. An ecological risk assessment of lead shot exposure in non-waterfowl avian species: Upland game birds and raptors. Environ. Toxicol. Chem. 15: 4-20. [CrossRef]

14. Kim, E.Y., Goto, R., Iwata, H., Masuda, Y., Tanabe, S. and Fujita, S. 1999. Preliminary survey of lead poisoning of Steller's sea eagle (Haliaeetus pelagicus) and white-tailed sea eagle (Haliaeetus albicilla) in Hokkaido, Japan. Environ. Toxicol. Chem. 18: 448-451. [CrossRef]

15. Kobayashi, Y., Shimada, A., Umemura, T. and Nagai, T. 1992. An outbreak of copper poisoning in Mute swans (Cygnus olor). J. Vet. Med. Sci. 54: 229-233. [Medline] [CrossRef]

16. Kuritani, T. and Nakamura, E. 2002. Precise isotope analysis of nanogram-level $\mathrm{Pb}$ for natural rock samples without use of double spikes. Chem. Geol. 186: 31-43. [CrossRef]

17. Kuritani, T. and Nakamura, E. 2003. Highly precise and accurate isotopic analysis of small amounts of $\mathrm{Pb}$ using $205 \mathrm{~Pb}-204 \mathrm{~Pb}$ and $207 \mathrm{~Pb}-204 \mathrm{~Pb}$, two double spikes. J. Anal. At. Spectrom. 18: 1464-1470. [CrossRef]

18. Kurosawa, N. 2000. Lead poisoning in Steller's sea eagles and white-tailed sea eagles. First symposium on Stellar's and white-tailed sea eagles in east Asia. Wild Bird Society of Japan, Tokyo.

19. Lovette, I. J. and Fitzpatrick, J. W. 2016. Avian Anatomy. Handbook of Bird Biology, 3rd ed., John Wiley \& Sons. Hoboken.

20. Ochiai, K., Hoshiko, K., Jin, K., Tsuzuki, T. and Itakura, C. 1993. A survey of lead poisoning in wild waterfowl in Japan. J. Wildl. Dis. 29: 349-352. [Medline] [CrossRef]

21. Pain, D. J. and Amiard-Triquet, C. 1993. Lead poisoning of raptors in France and elsewhere. Ecotoxicol. Environ. Saf. 25: 183-192. [Medline] [CrossRef]

22. Pain, D. J., Sears, J. and Newton, I. 1995. Lead concentrations in birds of prey in Britain. Environ. Pollut. 87: 173-180. [Medline] [CrossRef]

23. Pain, D. J., Fisher, I. J. and Thomas, V. G. 2009. A global update of lead poisoning in terrestrial birds from ammunition sources. pp. 99-118. In: Ingestion of Lead from Spent Ammunition: Implications for Wildlife and Humans, Peregrine Fund, Boise.

24. Pain, D. J., Mateo, R. and Green, R. E. 2019. Effects of lead from ammunition on birds and other wildlife: A review and update. Ambio 48: 935-953. [Medline] [CrossRef]

25. Pebesma, E. 2018. Simple features for R: standardized support for spatial vector data. $R J$. 10: 439-446. [CrossRef]

26. Saito, K. 2009. Lead poisoning of Steller's Sea-Eagle (Haliaeetus pelagicus) and Whitetailed Eagle (Haliaeetus albicilla) caused by the ingestion of lead bullets and slugs. Ingestion of Lead from spent Ammunition: Implications for Wildlife and Humans. pp. 302-309, Peregrine Fund, Boise.

27. Scheuhammer, A. M. and Norris, S. L. 1996. The ecotoxicology of lead shot and lead fishing weights. Ecotoxicology 5: 279-295. [Medline] [CrossRef]

28. Team, R. C. R. 2013. A Language and Environment for Statistical Computing. R Foundation for Statistical Computing, Vienna.

29. Vallverdú-Coll, N., Mougeot, F., Ortiz-Santaliestra, M. E., Castaño, C., Santiago-Moreno, J. and Mateo, R. 2016. Effects of lead exposure on sperm quality and reproductive success in an avian model. Environ. Sci. Technol. 50: 12484-12492. [Medline] [CrossRef]

30. Wickham, H. 2016. ggplot2: Elegant Graphics for Data Analysis. Springer-Verlag, New York.

31. Yabe, J., Nakayama, S. M. M., Ikenaka, Y., Yohannes, Y. B., Bortey-Sam, N., Oroszlany, B., Muzandu, K., Choongo, K., Kabalo, A. N., Ntapisha, J., Mweene, A., Umemura, T. and Ishizuka, M. 2015. Lead poisoning in children from townships in the vicinity of a lead-zinc mine in Kabwe, Zambia. Chemosphere 119: 941-947. [Medline] [CrossRef] 